\title{
Conjure Feminism: Toward a Genealogy
}

\author{
Kinitra Brooks ${ }^{1}$, Kameelah L. Martin ${ }^{2}$ and LaKisha Simmons ${ }^{3}$ \\ ${ }^{1}$ Department of English, Michigan State University, East Lansing, MI, USA, ${ }^{2}$ African American Studies \\ Program \& Department of English, College of Charleston, Charleston, SC, USA and ${ }^{3}$ Department of \\ History, University of Michigan, Ann Arbor, MI, USA \\ Corresponding authors.kdbrooks@msu.edu, martink12@cofc.edu and kisha@umich.edu.
}

We are a people. A people do not throw their geniuses away. And if they are thrown away, it is our duty as artists and as witnesses for the future to collect them again for the sake of our children, and, if necessary, bone by bone.-Alice Walker

The idea for this special issue on "Conjure Feminism" arose as the three of us sat around and talked about gardens, conjuring, and how our ancestors used the earth for survival. Conjure Feminism became a way to think specifically about the enduring histories of Black women's knowledge-production that began with the lessons we learned at our grandmothers' kitchen tables and are woven into the fabric of Black women's writing practices: motherwit, root medicine, food as ancestral memory, mothering, and spirit work. We also wanted to highlight the importance of specific places Black women have claimed as their domain within their homes, their gardens, and their kitchens, and how such spaces were empowered not only by their knowledge, but also by that of their foremothers. We wanted a phrase that captured and privileged this inherited wisdom; a concept that highlighted Black embodied theories of being and a Black womanist sense of space, time, and ethics. Conjure Feminism did that work for us.

\section{Conjuring in Black Feminist Thought}

Conjure Feminism has a long genealogy in Black feminist thought. As long as Black women have been a part of the academy, so too has there been work on conjure. Marjorie Pryse and Hortense Spillers saw Black women's "folk magic as art and fiction as a form of conjuring" in their book Conjuring: Black Women, Fiction, and Literary Tradition (Pryse and Spillers 1985, 2). Conjuring marks an important moment in Black feminist literary criticism. Pryse and Spillers give us permission to link Black women's storytelling to the intangible, to other ways of knowing that Black women have inherited from their mothers, "other mothers," and foremothers before them. They acknowledge how Black women's writing challenged "the authenticity and accuracy of an American history that failed to record their voices and a literary history that - written by Black men as well as white- has compounded that neglect" (3).

Indeed, Black women's fiction, in particular, has been a reckoning force through which sistas (real and imagined) have "reclaimed their time" and carved out a 
specifically Black and feminist/womanist agenda. In hindsight, it is much easier to recognize the history of Black women's literature as an intellectual tradition worthy of study and preservation. Black women as metaphorical conjure women-whipping up tales of survival and sainthood; love and lasciviousness; redemption and ratchedness alike-have refocused our literary attention on "connection rather than separation, transforming silence into speech, and [most important for our purposes] giving back power to the culturally disenfranchised" (5). Pryse and Spillers contend that Black women writers, as conjurers, "affirm the wholeness and endurance of a vision that, once articulated, can be shared -though its heritage, roots, survival, and intimate possession belong to Black women alone" (5). In this special issue, we want to push further their notion that Black women represent a "community of inheritors" who make it possible to recognize literary and philosophical ancestors such as gardeners, rootworkers, quilt-makers, and midwives, "and that however fleetingly history recorded their lives, there existed a woman's tradition, handed down along female lines” (4). The philosophical implication is that novelists and thinkers such as Alice Walker, Toni Cade Bambara, Audre Lorde, Toni Morrison, Gloria Naylor, and Zora Neal Hurston were privy to an intellectual and theoretical tradition that predates literacy and the written word altogether-Conjure Feminism.

Conjuring is as ancient as woman herself and, in the practice of Africana women, has been a Black feminist spiritual tool that protects, sustains, and empowers. To be certain, the conjuring arts are not monopolized by the highly melanated or the femininegendered; but we argue that Black and female positionality informs a particular spiritual praxis that "can be shared-though its heritage, roots, survival, and intimate possession belong to Black women alone" (5, emphasis added). Women have fought for control over reproduction and whether or not to give life from their womb; but for Black women, this struggle took on a particular urgency during slavery in the Americas. Oral and written histories corroborate that enslaved Black women used their intimate knowledge of the earth and their bodies to practice contraception and abortion. Enslaved Black women created reproductive knowledge and philosophical positions around abortion. When considering how antithetical abortion is to traditional West African belief, we can better observe how enslavement necessitated a paradigm shift actualized as Conjure Feminism. ${ }^{1}$ Africana women had reason to resist birthing children conceived by sexual violence, arranged copulation, or who were destined to a life of enslavement. Circumstances dictated a practice of contraception and abortion wherein leaves, roots, and tree bark were used to evacuate the uteruses of women who otherwise had little control over their bodies. In this instance, it is the circumstances and methods unique to Africana women that qualify such points of privilege over one's body as a type of Conjure Feminism.

If we look intently, we can see Conjure Feminism functioning within Black female intellectual histories all around us. If we think about how feminist writer Audre Lorde articulates the "erotic moment" as something that can be simultaneously female, sensual/sexual, divine, life-giving (reproductive), and pushes us toward our best selvesit is not a far intellectual leap for the conjure feminist to link Lorde's theoretical discourse to the Yoruba deity, Oshún (Lorde 1994). Lorde intellectualizes sensuality as a source of feminine power, but does so within a Western, academic context. We argue, however, that the "power of the erotic" is an ancient African epistemology that is being invoked by way of cultural memory. What Lorde articulates as erotic power is more fully fleshed out in the lore and sacred wisdom of Oshún. Erotic power has always been hers; "She is art which brings mental and spiritual pleasure," 
and Black women, particularly those strewn across the diaspora, have always already had a conjure feminist whose energy, whose konnoissance, they could call upon (Edwards and Mason 1998, 98). ${ }^{2}$ Oshún is one of many ancient conjuring foremothers whose divine attributes so often are reduced to disempowered emotions of love, physical pleasure, and the sweet coquettishness of femininity, but that extend much further. She is a master of strategy and controls the marketplace and flow of currency (101).

Her place in ensuring procreation of the human species is no triviality. She is quite literally giving us life. She is also a healer and "has a deep relationship with witchcraft, powders, charms, amulets, and malevolent forces" (101). The apotheosis of the Haitian lwa, Erzulie, is another fitting example of Africana women cogently stoking the coals of the ancient wisdom of their African antecedents and making it anew. Joan Dayan has argued that Erzulie is the embodiment of Haitian women's history with slavery and the feminine divine (Dayan 1998). Zora Neale Hurston, in Tell My Horse, also reminds us of our conjure feminist past in her description of the Haitian Mambo (priestess) who, dancing toward ecstasy, lifts her skirts to allow devotees to kiss her "sex organs" in spiritual answer to the question "What is truth?": "The ceremony means that this is the infinite, the ultimate truth. There is no mystery beyond the mysterious source of life" (Hurston 1938/ 1990, 113). Women, in Haitian Vodou tradition, are believed to be the poto mitan, the central pole through which the lwa, divinity, and life itself descend from the invisible world. ${ }^{3}$ The feminine divine is not an abstract concept, but a living, breathing tradition in the form of Black women's bodies. Put another way, "we ain't new to this."

Black feminist philosopher Kristie Dotson centers her research on Black women's ways of knowing. Dotson defines epistemic exclusion as an oppressively "unwarranted infringement" on the right to actively contribute to "knowledge production" (Dotson 2014). Literally, rootwork became the foundation of pharmaceutical science as Black women ground up roots to put in salves and steeped leaves to make healing teas. Figuratively, rootwork is an active part of the spirit work that informs Black women's epistemic agency: knowledge practices infused with traditional African religious practices that are put into action-used to both heal and harm as part of systems of belief. In our scholarship, we have openly and consistently pushed back against the epistemic exclusion of Black women's knowledge practices.

Dotson's work helps illuminate how generations of family knowledge fade away. We would like to take a moment to turn to one example of many, a story that comes from Kinitra Brooks's family. Many of us can tell similar stories; by placing her great grandmother, Myrtle Anderson, in this introduction, we hope to highlight Black (conjure) feminist knowledge practices that come from outside of the academy and why we are privileging other ways of knowing as intellectually robust and theoretical.

\section{Interlude: Learning from Mama Myrt}

Mama Myrt became a wife, mother, and entrepreneur-she was a licensed beautician who worked out of her home-but her ancestral role as a rootworker, conjure woman, and community healer leads the unfolding narrative of Kinitra's life's work. As a member of her family whose traditions of healing go back twelve generations, Mama Myrt holds legendary status. The erosion of Kinitra's family's connection to the land began with their decision to move to New Orleans from Plaquemines Parish. In the city, her family began to prosper economically because her grandmother Clara Mae Dunn, née Anderson, and grandfather Wilbert England Dunn graduated from college and became schoolteachers, launching subsequent generations into similar paths of 
postgraduate degrees and careers in education, civil service, and the corporate world. Yet, in this economic and professional success and stability of which Kinitra is a direct product, she continues to wonder, what have we lost in our aspirations toward Black middleclass achievement? And how does her insistence on recovering her family's roots in conjure, gardening, and rootwork begin to restore her family's deep connection to the land?

Kinitra has a backyard garden in which she grows okra, jalapeños, cucumbers, and peppers. She is feeding her family and learning how soil works as she soothes her soul and communes with her great-grandmother's spirit. The presence of her maternal ancestors is manifest as she moves her large brown hands in the soil and wipes the sweat off her brow, her upper-arm fat jiggling just like that of her Mama Myrt. The journey has not been perfect. Tomatoes have proven to be a constant reflection of Kinitra's failures as a burgeoning horticulturist. Her garden began to feed a family of possums, which eventually nested in the air-conditioning ducts under her home. They tore the duct system to shreds, and the repairs set her back $\$ 4,000$. There was one particular summer when Kinitra intuited that she was on the right path. She had brought a basket of okra to her mother, who was visiting, and they began to shuck the corn she'd purchased from the supermarket. Kinitra's mother's eyes lit up and she exclaimed, "Oh, we used to do all of this when I was a little girl! We would go to the country by your MonMon (grandmother Clara, who is Myrtle's only child) people in Plaquemines Parish and get fresh seafood and fresh vegetables every other weekend. It was always better than what they had for sale in the city." Her mother began to reminisce about how she loathed the country but regrets forgetting how to work the land. And at the end of her stories, she looked up at Kinitra, her oldest daughter, and proclaimed, "I want to learn how to do this again. Can you teach me?" This moment completes the circle, as Kinitra's mother reveals her yearning for some of the peace that the spirit work has provided her daughter's soul. It is healing. This is knowledge. This is Myrtle's medicine, spirit work as a conduit for memories and a vulnerability between mother and daughter-descendants with a complicated, loving, and fiery relationship all their own.

The growing understanding of what Kinitra's family, as well as our own, has lost and what we all are slowly regaining reflects a reality commonly seen across the African diaspora. Black families navigate a potent mix of systemic racism, misogynoir, white supremacy, and colonialism. Just as we are using Myrtle's medicines as a source of epistemic agency to heal family wounds and foster difficult conversations, we feel the need to extend this discussion and activate on a larger scale the knowledge frameworks of Black southern and Caribbean women thought leaders through the development of Conjure Feminism. What have we inherited from Conjure Feminists Queen Nanny, Marie Laveau, Tituba, and the Grandmamas, Mambos, and Madrinas for whom Western history does not hold space? How has the Westernized space of the academy colonized Black folx into accepting these ancient philosophies, which are simultaneously spiritual and intellectual, trivial and superstitious? How can intellectual communities recognize Conjure Feminism as an extension of Black feminist theory and apply it to African and African diaspora studies? This is the central question we hope this special issue can begin to answer.

\section{Wisdom in Conjure Feminism}

Conjure Feminism is an ongoing epistemological project that we have only just begun. We have yet to fully arrive at a hard and fast definition of the construct, but the essays in 
this special issue help work through the possibilities of what it can be. Contained within Conjure Feminism is a set of ethical demands that derive from African-based and Christian practices and are grounded in the ontological potential in quotidian Black life. We want to tap into the power of ritual and Black women as agents of transformation for renewing and creating (Fett 2002, 53). We have begun to outline four basic tenets, as we distill major topics of inspiration from oral traditions grounded in our own family practices, spiritual experiences, theories, and narratives grounded in southern and Caribbean folklore:

1. There are consequences for your actions.

This system of ethics demands a reimagining of what is right or wrong. Morality both shifts and remains steadfast within the communal space. What stands firm is that there are material, communal, and spiritual consequences for one's actions that cause harm. Conjure Feminism also allows for ontological shifts such as being cursed and/or outcast from the communal space both as an individual and as a family. Mama Myrt's greeting of "Hey Baby, who your people?" was a quick way to establish the importance of the individual she was meeting as shaped by their family's name and reputation within the community.

2. Death is not an ending but a transition.

Conjure Feminism operates from a hyper-awareness of the conflation of time as the past, present, and future coexist together, building upon Bonnie Barthold's insistence that "the dead are not dead" (Barthold 1981, 3). There exists an active privileging of the work done in the interstices of time. Cornelia Walker Bailey expresses this with the concept of "Dayclean" (Bailey and Bledsoe 2000, 2). Dayclean is a Gullah Geechee term that refers to that specific moment when night turns to day. It is a generative time that low-country Black folx seize upon to renew hope as well as complete the practicalities of the systems that keep families running, or what Patricia Hill Collins refers to as motherwork (Collins 1990). It is at Dayclean that we become new spiritually, mentally, and otherwise.

3. One is beholden to the Ancestors as well as to future generations.

There is a sustained rejection of the linearity of time, for time is conflated and cyclical. Tanisha C. Ford tweeted, "Time is a concept, a suggestion. It's malleable, ductile, pliable, flexible. It's textured and capacious" (Ford n.d.). Individualism is not discouraged, but communalism is privileged. The pragmatism of the quotidian is situated within the circular demands of what Barthold refers to as "Black Time" (Barthold 1981, 2), which requires an acknowledgment of the communal past as synonymous or coextensive with the present and future.

4. Spirit work is necessary for our physical, emotional, and psychological health. Kameelah Martin defines spirit work as "ritual practices of African derived religious practices that evolved in the New World: Obeah, Vodou, Lucumí, Espiritismo, Conjure and Hoodoo, Candomblé, Voodoo, and others" as well as "communication with supernatural entities" (Martin 2012, 1-3). The spiritual framework of Conjuring is not associated with any specific religion but is a network of various spiritual practices grounded in the veneration of and communication with the dead, as seen through the Ancestors. 


\section{Embodied Theories and Black Womanist World-Making}

Conjure Feminism is an embodied theory that recognizes the importance of spirit work in the development of Black feminist intellectual traditions rooted in what Dotson refers to as the epistemic agency of Black women. It is an active inheritance that comes through our grandmothers' medicines and domesticity. One piece of this recovery project consists of following the intellectual threads of the previously mentioned matriarchs and the influence of other knowledge systems - such as womanist theology, Black liberation theologies, and Africanized Christian practices-on the development of Conjure Feminism. How central were rootwork and herbology to the medical workers on plantations? What role did dream-interpretation and reading otherworldly signs play in sowing seeds, conception, healing, and harvesting? How active were Black women in these practices? What did their medicinal gardens and domestic ministries look like? What emphasis was placed on spiritual health and knowledge in curing the physical body? What ancestral memory do we imbibe in Black women's culinary crafts? How have we learned to tend to our own Black fem(me)inine bodies through these lineages? What was lost as Black communities strove to become more "respectable" and mirror mainstream (that is, white capitalist) medical practices? Did we lose access to the conjure feminist traditions of our foremothers?

Spillers believes in the presence of a Blackness that is brimming with agency and complexity. Spillers's work is so generative for us because we seek to claim, as she states, "the monstrosity" of the conjure woman, "a female with the potential to 'name." In particular, we are using Conjure Feminism to "rewrite ... a radically different text for female empowerment" (Spillers 1987, 80). Here we can recall the subversive presence of Dona Beatriz Kimpa Vita-the world-shifting power plays she was able to make against the white supremacy and patriarchy of the Catholic Church at the height of its colonial power-and her surety in the Blackness of Jesus." In "Mama's Baby, Papa's Maybe," Spillers purposefully interweaves Western theories of being into Black feminist frameworks, which she believes to be equally complex, although in different ways. This act expanded our idea of what complexity and "high" theory could be, a journey that leads right back to mother wit, folklore, and, for us, the Africanized Christian faith practices of our maternal ancestors. We are building upon Spillers's work to include spirit work as foundational to the complexities of Black women's philosophical cosmologies. Sharla M. Fett insists, "African American healing under slavery reflected a definition of power as the capacity not only to control but also to create and transform" (Fett 2002, 52). It is this capacity for world-building, and how it transitioned to postemancipatory cosmologies of the Black women we emphasize that we are most interested in analyzing. Shana Almeida insists that Black women's epistemic agency "must affirm the value of subjective, lived experience, and rejects Eurocentric, male-centered systems of knowledge production" (Almeida 2015, 82). This is the scaffolding of Conjure Feminism-and the meaning and beauty of embodied knowledge.

\section{Black Life and Black Death}

In taking up this call for "gaining the insurgent ground" of Black genderlessness, we hear Spillers asking us to think through a Black worldview, Black ways of being (Spillers 1987, 80). In this way, Conjure Feminism helps us center a concept of Black life. As we seek to define it, Black life is not another name for resistance. Black life is a new way of thinking through the past, the present, and the future. 
Black women have thought seriously about life with death and anti-Blackness around them. Conjure Feminism helps to underscore the ways in which Black enslaved women, for example, lived as fully human in spaces of dispossession that erased their humanity at every turn. When we use the term Black life, we want to underscore complicated and messy human emotions: depression, sadness, hate, love, ecstasy, and lust. Our scholarly work has also sought to illustrate the ways in which dehumanization has worked to deny African Americans' life stages. An analysis of Black life, then, interrogates the life cycle: thinking through the ancestors before us, infancy, girlhood, women's reproduction, middle-age and elderly life stages, and what comes after death. This enables us to see Black women's subjectivities shift and change over time and how Black women and girls interact with and imagine the world around them. In this definition of Black life, we see a Black feminist way of being human, defined not by Western individualism but by intergenerational relationships and deep connections to Black ancestors, ancestral traditions, and the afterlife.

The most well-known public meditation on Conjure Feminism can be seen in Beyonce's 2016 audiovisual album, Lemonade (Carter 2016). Lemonade ponders this generative power that connects history, the land, gardens, mothering, the womb, and ancestors to the intellectual tradition of "Conjure Feminisms." Lemonade conjures Black life, celebrating the victory we have over Black death. The scenes involving cooking and the vegetable garden forge not only a Black feminist sense of place on the plantation landscape, but the women gathered around harvesting, cooking, and preparing food are invested in the care of their radical feminist community. In "Plantation Futures," Katherine McKittrick (following Sylvia Wynter) focuses her discussion of Black life on "the plot": "The plot and plantation are, on the one hand, dichotomized and ambivalent geographies, and, on the other hand, the locations through which Blackness becomes rooted in the Americas: For African peasants transplanted to the plot [,] ... the land remained the earth.... [They] used the land to feed [themselves]; and to offer first fruits to the earth" (McKittrick 2013, 10).

Gardens play a central role in Dylan Penningroth's history of enslaved notions of property and community. Penningroth notes that often, masters would allow enslaved workers a plot of land or a "garden patch next to their cabins" (Penningroth 2003, 48-49). Plots and gardens were not spaces of complete freedom: plantation owners and overseers often enforced rules about size, placement, and what could be grown on these plots. Plots forced enslaved people to work longer (as they tended their gardens in their "free" time) and also gave plantation owners the whim to refuse the provision of food to the enslaved. But formerly enslaved interviewees often recalled the landscape of the garden just outside the slave quarters-as in the image in Lemonade. Elizabeth Ross Hite recalled, “Sure, we ate good food ... Talkin' about garden, shucks, you ain't seen no garden. We had a garden right in front of our quarter. We planted everything in it. Had watermelon, mushmelon, and a flower garden" (Clayton 1990, 101). In this way, that landscape just in front of the quarters could be a place of freedom. But Hite also recalled a "mean master" at a nearby plantation. There, "Old lady Oater ran away and built a home in de ground. She had six children. De driver caught her one day and whipped her to death. He beat her until her skin fell off and she died. Den he unloosened her from de tree and buried her in de ground in front of de quarters" (102). How do we understand these two very different images: two plots, landscapes that exist in front of the quarter? Conjure Feminism helps see both life and death existing in the same space simultaneously, where Black women work in the interstices of time and space. 
Mainstream Black folx-particularly those in the US South and the Global Southhave long claimed the wisdom of their familial matriarchs, yet have always felt the necessity to supplement and, many times, to replace this knowledge with more learned and ultimately Western intellectual pursuits. Conjure Feminism liberates the diasporic knowledge and folkloric practices of spirit work. Its nonrational, cosmological framework provides Black folx with the fluidity necessary to live in a constantly shifting, perilous world. To further demonstrate the theoretical dimensions of Conjure Feminism, we have chosen to include in this special issue pieces that explore Black life and love, Black motherhood, alongside writings that focus more specifically on various types of haunting and visitations of spirit.

Although Conjure Feminism is pulled from the knowledge of the ancestors, what becomes clear when reading these essays together is how Conjure Feminism helps us see Black liberation and Black futures anew. Lindsey Stewart, in "An Inside Thing to Live By" takes a close look at the "willful retention of conjure" of granny midwives as a particular kind of political refusal enacted by Black feminist visionaries who are looking for new modes of liberation. Theresa Hice-Fromille, too, considers intergenerational learning and pulls on family history in a poetic musing called "The Queerness of Black Matriarchal Praxis." Here, inheritance exists outside of Western, heteropatriarchal family structures; Hice-Fromille looks toward queer mothering as a place of healing.

Many of the writers in this special issue also focus on ancestral presence. LeConté J. Dill combines poetry and autoethnography to explore child loss, mothering, and daughtering, alongside the story of her ancestors. At all points, Dill connects the ancestral presence with her own story of "waiting for [her] miracle" and "Breathing [her miracle] into Being." Meanwhile, drea brown reads the ancestral hauntings in the work of Phillis Wheatley and Lucille Clifton.

Both Ayanna Dozier and co-authors gloria wilson, Joni Boyd Acuff, and Vanessa López use conjuring as a methodological approach to the creation and interpretation of Black/WoC feminist art and arts-based practice. Dozier reads a Julie Dash short film, Praise House (1991) as "conjure-cinema" that "enacts ... an epistemological rupture," opening a new way of understanding humanness. As visual artists, wilson, Acuff, and López use their musing to describe their critical, collective conjuring as a WoC practice of "way-finding" through aesthetic engagement with themes of memory, trauma, and joy.

The issue concludes with Elizabeth Pérez's deep dive into the metaphysics and cultural politics of Azealia Banks's very public practice of Palo Mayombe. We offer this special issue as an entry point to Conjure Feminism, inviting scholars and thinkers to expand and add more dimension to the theory as we return to our mothers' gardens and embrace all that we have inherited.

\section{Notes}

1 In traditional Akan belief, for instance, it is one's duty to the Ancestors to produce generations and ensure that the familial line continues. Those who could not reproduce were believed to be in conflict with the Ancestors and were stigmatized in the community.

2 "Konnoissance" is a Haitian Kreyol word used in the spiritual tradition of Vodou to denote spiritual knowledge (see Deren 2004, 156-58).

3 Riva Nyri Précil, a Haitian spiritualist and serviteur, discusses during a virtual lecture the poto mitan

(a Kreyol word meaning "central pillar") as a metaphor for the importance of women in the tradition (Précil 2020). 
4 Dona Beatriz Kimpa Vita was a late seventeenth-century subject of the Kongo Kingdom who led a fiery resistance movement against the Catholic Church, grounded in her insistence that she was possessed by Saint Anthony, and firm in her belief that Jesus was Kongolese.

\section{References}

Almeida, Shana. 2015. Race-based epistemologies: The role of race and dominance in knowledge production. Wagadu: A Journal of Transnational Women's and Gender Studies 13 (Summer): 79-105.

Bailey, Cornelia, and Christena Bledsoe. 2000. God, Dr. Buzzard, and the Bolito Man: A saltwater Geechee talks about life on Sapelo Island. 1st ed. New York: Doubleday.

Barthold, Bonnie J. 1981. Black time: Fiction of Africa, the Caribbean, and the United States. New Haven, Conn.: Yale University Press.

Carter, Beyoncé Knowles. 2016. Lemonade. Parkwood Entertainment.

Clayton, Ronnie, ed. 1990. Mother wit: The ex-slave narratives of the Louisiana Writers Project. New York: Peter Lang.

Collins, Patricia Hill.1990. Black feminist thought: Knowledge, consciousness, and the politics of empowerment. New York: Routledge.

Dayan, Joan. 1998. Erzulie: A woman's history of Haiti. In The woman, the writer, and Caribbean society: Essays on literature and culture. ed. Helen Pyne-Timothy. Los Angeles: UCLA CAAS Publications.

Deren, Maya. 2004. Divine horsemen: The living gods of Haiti. Kingston, N.Y.: McPherson.

Dotson, Kristie. 2014. Conceptualizing epistemic oppression. Social Epistemology 28 (2): 115-38.

Edwards, Gary, and John Mason. 1998. Black gods: Örișà studies in the new world. Revised 4th ed. Brooklyn, N.Y.: Yorùbá Theological Archministry.

Fett, Sharla. 2002. Working cures: Healing, health, and power on southern slave plantations. Chapel Hill: University of North Carolina Press.

Ford, Tanisha C. n.d. Twitter.

Hurston, Zora Neale. 1938/1990. Tell my horse: Voodoo and life in Haiti and Jamaica. New York: HarperCollins.

Lorde, Audre. 1994. Uses of the erotic: The erotic as power. In Wild women don't wear no blues: Black women writers on love, men, and sex, ed. Marita Golden. New York: Anchor Books.

Martin, Kameelah. 2012. Conjuring moments in African American literature: Women, spirit work, and other such hoodoo. New York: Palgrave McMillan.

McKittrick, Katherine. 2013. Plantation futures. Small Axe: A Journal of Carribean Criticism 17 (3): 1-15.

Penningroth, Dylan. 2003. The claims of kinfolk: African American property and community in the nineteenth-century south. Chapel Hill: University of North Carolina Press.

Précil, Riva Nyri. 2020. Haitian Vodou. Virtual guest lecture. African American Studies Program. College of Charleston. October 7 and 9.

Pryse, Marjorie, and Hortense J. Spillers, eds. 1985. Conjuring: Black women, fiction, and literary tradition. Bloomington: Indiana University Press.

Spillers, Hortense. 1987. Mama’s baby, papa’s maybe: An American grammar book. Diacritics 17 (2): 64-81.

Kinitra Brooks holds the Audrey and John Leslie Endowed Chair in Literary Studies in the Department of English at Michigan State University. Dr. Brooks specializes in the study of black women, genre fiction, and popular culture. She currently has two books in print: Searching for Sycorax: Black Women's Hauntings of Contemporary Horror (Rutgers University Press, 2017), a critical treatment of black women in science fiction, fantasy, and horror, and Sycorax's Daughters (Cedar Grove Publishing, 2017), an edited volume of short horror fiction written by black women. Her current research focuses on portrayals of the Conjure Woman in popular culture.

Kameelah L. Martin's scholarly expertise sits at the crossroads of African diaspora literature(s) of the US and Caribbean and folklore studies. As a cultural studies scholar, she is trained in the African American literary and vernacular traditions with emphasis on twentieth- and twenty-first-century prose. Her interdisciplinary reach also involves broader interests, such as comparative literature(s) of the African diaspora. She is deeply committed to the fields of African diaspora studies, literature, folklore, and film studies. As such, her research and teaching interests fall widely under this individualized humanities-based umbrella. In 
2013, Palgrave McMillan published her first monograph, Conjuring Moments in African American Literature: Women, Spirit Work, and Other Such Hoodoo, which engages how African American authors have shifted, recycled, and reinvented the conjure woman figure primarily in twentieth-century fiction. Dr. Martin is also the author of Envisioning Black Feminist Voodoo Aesthetics: African Spirituality in American Cinema (Lexington, 2016) which explores the treatment of the priestess figure in American cinema.

LaKisha Michelle Simmons is a historian of African American gender history specializing in Black girlhood, history of the family, Southern history, history of sexuality, reproductive health and Black geographies in the nineteenth and twentieth centuries. Simmons is the author of Crescent City Girls: The Lives of Young Black Women in Segregated New Orleans (University of North Carolina Press, 2015), which won the SAWH Julia Cherry Spruill Prize for best book in Southern women's history and received Honorable Mention for the ABWH Letitia Woods Brown Memorial Book Award for the best book in African American women's history.

Cite this article: Brooks K, Martin KL, Simmons LaK (2021). Conjure Feminism: Toward a Genealogy. Hypatia 36, 452-461. https://doi.org/10.1017/hyp.2021.43 